Egyptian Journal of Aquatic Biology \& Fisheries

Zoology Department, Faculty of Science,

Ain Shams University, Cairo, Egypt.

ISSN $1110-6131$

Vol. 24(3): 97- 107 (2020)

www.ejabf.journals.ekb.eg

\title{
Population dynamic of Periophthalmodon septemradiatus (Hamilton, 1822) living along the Hau River, Vietnam
}

\section{Lam T. Tran' ${ }^{1}$ and Quang M. Dinh ${ }^{2 *}$}

1. Department of Basic Science, Faculty of Education, Bac Lieu University, 8 ward, Bac Lieu city, Bac Lieu 910000, Vietnam

2. Department of Biology, School of Education, Can Tho University, Xuan Khanh ward, Ninh Kieu district, Can Tho 900000, Vietnam

*Corresponding Author: dmquang@ctu.edu.vn

ARTICLE INFO

Article History:

Received: February 6, 2020

Accepted: April 28, 2020

Online: May 2020

Keywords:

Exploitation rate, mortality,

Population dynamic,

P. septemradiatus,

Hau River,

Vietnam
ABSTRACT

This study provides the biology of the population of Periophthalmodon septemradiatus, as a basis for species conservation. The result analysis of 3,436 individuals collected on a monthly basis starting from July 2017 to June 2019. Five sites including Long Duc, Long Phu, Soc Trang (LD), An Lac Tay, Ke Sach, Soc Trang (ALT), Phu Thu, Cai Rang, Can Tho (PT), Tan Hung, Thot Not, Can Tho (TH), and Binh Duc, Long Xuyen, An Giang (BD) were conducted along the Hau River from the estuary to the upstream of the river. It showed that the male to female ratio ranged from $1.36: 1.00$ to $1.87: 1.00$. Although this species' $L \infty$ was $12.6 \mathrm{~cm}$ for all five populations, the growth coefficient $(K)$ and $t_{0}$ varied with studied sites. The $K$ value ranged from $0.49 \mathrm{yr}-1$ (PT) to $1.6 \mathrm{yr}-1$ (BD), whereas the $t_{0}$ was -0.12 in $\mathrm{BD}$ and -0.43 in PT. Likewise, the longevity of this species was the lowest value in BD (1.88 yr.) and the highest one in PT $(6.12 \mathrm{yr}$.). The total mortality and natural mortality coefficients of fish populations displayed the highest values in the $\mathrm{BD}(Z=4.11, M=3.14)$ and the lowest one in $\mathrm{PT}(Z=1.68$, $M=1.46)$. Conversely, the highest and lowest values of the fishing mortalities $(F)$ were in TH (1.58) and PT (0.22), respectively. The species populations were subjected to overfishing in ALT and TH.

\section{INTRODUCTION}

The exploitation rate estimated from the analysis of the yield-per-recruit has a strong relationship with fisheries management (Beverton and Holt, 1957). The growth and mortality parameters are used to assess the fish population (Ricker, 1975). The growth performance with combined analysis of growth and asymptotic length relationship are related to the variations of fish growth rate between genders and locations (Pauly and Munro, 1984). In the Mekong Delta, the gobies diversify yet the data on the population is fragmented for some gobiid species such as Pseudapocryptes elongatus (Tran et al., 2007) and Parapcryptes serperaster (Dinh et al., 2015b). Due to the overexploitation with various fishing gears (Trinh and Tran, 2012), it leads to the reduction of fish species in the Mekong Delta including the gobies (Diep et al., 2014). For example, the population of Glossogobius giuris (Dinh et al., 2017), Boleophthalmus boddarti (Dinh, 2017), Stigmatogobius pleurostigma (Dinh and Nguyen, 2018) and Trypauchen vagina (Dinh, 2018a) have been subjected to overfishing. There is a need for studies on fishing status of gobiid species.

The genus of Periophthalmodon (Gobiidae: Oxudercine) has three species including $P$. freycineti, $P$. schlosseri and P. septemradiatus (Murdy, 1989; Murdy, 2011; Murdy and Jaafar, 
2017). Only $P$. schlosseri and $P$. septemradiatus are recorded in Vietnam (Tran et al., 2013). The species $P$. septemradiatus is an amphibious fish (Martin and Bridges, 1999) and widely distributes in the mangrove swamps and muddy areas in the Asian regions (Murdy, 1989; Murdy, 2011; Murdy and Jaafar, 2017). In the Mekong Delta of Vietnam, this fish can live from estuary to the upstream of the river systems (Dinh et al., 2019; Mai et al., 2019; Dinh et al., 2020). There is no information on the population biology of this fish, especially from the estuary to upstream sites of the Hau River, where its population tends to be overfished (Dinh et al., 2020). This study, therefore, aims to contribute to the knowledge of the biological features of the species as to further understand of its stock and management.

\section{MATERIALS AND METHODS}

\section{Study site}

This study was conducted from July 2017 to June 2019 in muddy regions of tributaries of Hau River including Long Duc, Long Phu, Soc Trang (LD; 942'55.4"N 10604'28.4"E), An Lac Tay, Ke Sach, Soc Trang (ALT; 9 $49^{\prime} 52.4^{\prime \prime N} 105^{\circ} 59^{\prime} 44.5^{\prime \prime} \mathrm{E}$ ), Phu Thu, Cai Rang, Can Tho (PT; 9 59'45.06"N $\left.105^{\circ} 48^{\prime} 22.73 " \mathrm{E}\right)$, Tan Hung, Thot Not, Can Tho (TH; 10 $\left.12^{\prime} 07.17^{\prime \prime N} 105^{\circ} 34^{\prime} 43.89 " \mathrm{E}\right)$ and Binh Duc, Long Xuyen, An Giang (BD; $10^{\circ} 24^{\prime} 03.54^{\prime \prime N} 105^{\circ} 25^{\prime} 10.82 " \mathrm{E}$ ) (Fig.1). In the studied sites, there are typically two seasons including dry season with little precipitation (January to May) and wet season with roughly $400 \mathrm{~mm}$ precipitation per month (June to December). The mean annual temperature in this region is $\sim 27{ }^{\circ} \mathrm{C}$. The tide of the study regions is semi-diurnal (Le et al., 2006). The mudflat characterized by silt, clay, sand, and organic matter, and the distance from the river bank to the riverbed of the mudflat is nearly $2.5 \mathrm{~m}$ at the lowest tide (Dinh et al., 2019).

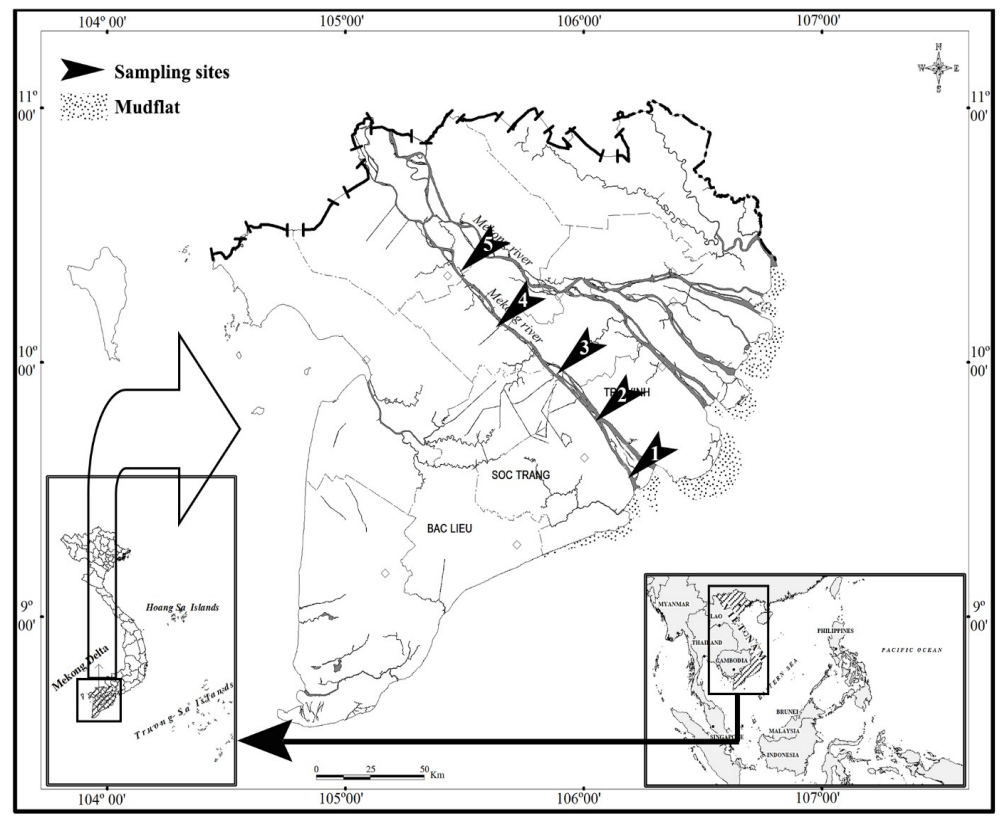

Fig.1. The sampling map in the Mekong Delta

(arrow: Sampling sites; 1: Long Duc, Long Phu, Soc Trang, 2: An Lac Tay, Ke Sach, Soc Trang, 3: Phu Thu, Cai Rang, Can Tho, 4: Tan Hung, Thot Not, Can Tho, and 5: Binh Duc, Long Xuyen, An Giang)

The flora in this area consisted mainly of Sonneratia caseolaris and Nypa fruticans, and the slopes of the river bank were $\sim 25^{\circ}$. These plant species and Cryptocoryne ciliata were predominantly found in ALT. The slopes of the riverbank in ALT were also $\sim 25^{\circ}$. There were no predominant trees found in the flora in PT which was near some industrial zones. Nauclea orientalis was the predominant tree of the flora in $\mathrm{TH}$ with the riverbank slopes of $\sim 45^{\circ}$. Sonneratia caseolaris was still appeared in TH but not in BD where the flora mainly consisted of Nauclea orientalis. Like TH, the slopes of the riverbank in BD were near to $45^{\circ}$ (Dinh et al., 2020). 


\section{Fish collection and analysis}

Fish specimens were collected monthly using traps and hands, along with the mudflat and mangrove forests in the studied regions. An area of $30 \mathrm{~m}^{2}(15 \mathrm{~m}$ along the riverbank and $2 \mathrm{~m}$ from the riverbank to the riverbed) in each site was chosen to collect fish on a monthly basis. Every field campaign lasted five days (one day per sampling site). After visual identification using external characteristics described by Khaironizam and Norma-Rashid (2003), the fish was stored in $4 \%$ formalin and transported to the laboratory. In the laboratory, the sex of P. septemradiatus was based on the urogenital papilla morphology, which was round in female and narrow in male (Dinh et al., 2020), and fish specimens were measured total length $(0.1 \mathrm{~cm})$.

\section{Data analysis}

The difference in male to female ratio of $1: 1$ was confirmed using $\chi^{2}$ at a meaningful value of $5 \%$. The $\chi^{2}$ test was performed by using SPSS v.21.

The length-frequency data of these fish were analyzed using FiSAT II software to estimate the population biological parameters (Gayanilo et al., 2005). Using The ELEFAN I, the procedure was performed to determine the asymptotic length $\left(L_{\infty}\right)$ and the growth parameter $(K)$ (Pauly and David, 1981; Pauly, 1982; Pauly, 1987). The length-converted capture curve was applied to estimate the total mortality rate $(Z)$ (Beverton and Holt, 1957; Ricker, 1975). The theoretical age parameter $\left(t_{0}\right)$ was calculated from the equation $\log _{10}\left(-t_{0}\right)=-0.3922-0.2752 \log _{10} L_{\infty}-1.038 \log _{10} K$ (Pauly, 1979). The equation $\log M=-0.0066-0.279 \log L_{\infty}+0.6543 \log K+0.463 \log T$ ( $L_{\infty}$ and $K$ were achieved from the ELEFAN I and $T$ is the mean annual water temperature $\left({ }^{\circ} \mathrm{C}\right)$ ) was used to estimate the natural mortality rate $(M)$ (Pauly, 1980). The fishing mortality $(F)$ was calculated as $F=Z-M$ and the exploitation rate $(E)$ was determined as $E=F / Z$ (Ricker, 1975).

The probability of capturing for each class size $\left(L_{c}\right)$ was estimated using the length-converted catch, and the fish length entry (Pauly, 1987). The knife-edge selection was performed to estimate the maximum yield exploitation rate $\left(E_{\max }\right)$ with a minimal increase of $10 \%$ of $Y K_{R}\left(E_{0.1}\right)$ and the reduction of stock to $50 \%\left(E_{0.5}\right)$ (Beverton and Holt, 1966). The growth performance $\left(\Phi^{\prime}=\log K+2 \log L_{\infty}\right)$ was used to compare the von Bertalanffy growth parameters of $P$. septemradiatus and other fishes dwelling in and out its habitat (Pauly and Munro, 1984). The longevity $\left(t_{\max }\right)$ was calculated using $t_{\max }=\frac{3}{K}$ (Taylor, 1958; Pauly, 1980).

\section{RESULTS}

\section{Sex ratio}

A total of 3,436 fish including 2,081 males and 1,355 females were collected at five sampling sites during the wet and dry seasons (Table 1). Although $P$. septemradiatus can live from estuary to upstream areas of Hau River, the number of fish decreased gradually from LD to BD (Table 1), which could be resulted from the difference in flora among these studied sites. In each sampling site, the number of male $P$. septemradiatus collected was significantly higher than that of females $\left(\chi^{2}, p<0.05\right.$ for all cases, Table 1).

Table 1. Sex ratio of Periophthalmodon septemradiatus along the Hau River

\begin{tabular}{lccc}
\multicolumn{1}{c}{ Sampling site } & No. of fish & No. of male and female & Sex ratio (M : F) \\
\hline Binh Duc, Long Xuyen, An Giang & 657 & $396: 261$ & $1.52: 1.00$ \\
Tan Hung, Thot Not, Can Tho & 649 & $384: 265$ & $1.45: 1.00$ \\
Phu Thu, Cai Rang, Can Tho & 691 & $418: 273$ & $1.53: 1.00$ \\
An Lac Tay, Ke Sach, Soc Trang & 730 & $421: 309$ & $1.36: 1.00$ \\
Long Duc, Long Phu, Soc Trang & 709 & $462: 247$ & $1.87: 1.00$ \\
\hline Total & $\mathbf{3 , 4 3 6}$ & $\mathbf{2 , 0 8 1 : \mathbf { 1 , 3 5 5 }}$ & $\mathbf{1 . 5 4 : 1 . 0 0}$ \\
\hline
\end{tabular}

\section{Population parameters}

The data on the length frequency of $P$. septemradiatus showed that the fish group had the smallest length of 4-5 cm and the largest length group is 12-13 cm (Table 2). Most of fish were caught from 6-7 cm to $10-11 \mathrm{~cm}$ in total length $(3,191 / 3,436, \sim 93 \%)$, indicating that the population of 
P. septemradiatus was in the growing and breeding groups. The length-frequency data analysis showed that five $P$. septemradiatus populations living at five sampling sites had 5-6 cohorts, e.g., 5-6 growth curves (Fig. 2).

Table 2. The number of $P$. septemradiatus caught from Hau River from July 2017 to June 2019

\begin{tabular}{|c|c|c|c|c|c|c|c|c|c|c|}
\hline \multirow{2}{*}{ Month } & \multicolumn{9}{|c|}{ Total length $(\mathrm{cm})$} & \multirow{2}{*}{ Total } \\
\hline & $4-5$ & $5-6$ & $6-7$ & $7-8$ & 8-9 & $9-10$ & 10-11 & 11-12 & $12-13$ & \\
\hline $07 / 2017$ & 5 & 4 & 20 & 27 & 23 & 19 & 14 & 9 & & 121 \\
\hline $08 / 2017$ & & 5 & 26 & 20 & 17 & 9 & 13 & 3 & 1 & 94 \\
\hline $09 / 2017$ & & 3 & 23 & 22 & 21 & 15 & 10 & 2 & & 96 \\
\hline $10 / 2017$ & & 1 & 15 & 27 & 23 & 25 & 6 & 1 & & 98 \\
\hline $11 / 2017$ & & 7 & 31 & 26 & 21 & 11 & 8 & 2 & & 106 \\
\hline $12 / 2017$ & & 5 & 22 & 40 & 34 & 14 & 16 & 6 & & 137 \\
\hline $01 / 2018$ & & 2 & 24 & 28 & 20 & 16 & 7 & 3 & & 100 \\
\hline $02 / 2018$ & & & 14 & 41 & 26 & 6 & 13 & 6 & & 106 \\
\hline $03 / 2018$ & & 4 & 6 & 29 & 28 & 24 & 26 & 5 & & 122 \\
\hline $04 / 2018$ & 1 & 19 & 29 & 31 & 25 & 24 & 23 & 3 & & 155 \\
\hline $05 / 2018$ & & 2 & 24 & 47 & 19 & 15 & 20 & 7 & & 134 \\
\hline $06 / 2018$ & & 8 & 20 & 16 & 36 & 37 & 26 & 2 & & 145 \\
\hline $07 / 2018$ & & 7 & 14 & 37 & 47 & 21 & 22 & 2 & & 150 \\
\hline $08 / 2018$ & & 12 & 28 & 23 & 30 & 24 & 22 & 10 & 1 & 150 \\
\hline $09 / 2018$ & & 10 & 35 & 32 & 21 & 30 & 18 & 4 & & 150 \\
\hline $10 / 2018$ & & 4 & 27 & 40 & 31 & 24 & 23 & 1 & & 150 \\
\hline $11 / 2018$ & & 4 & 26 & 42 & 25 & 24 & 24 & 4 & & 149 \\
\hline $12 / 2018$ & & & 15 & 30 & 49 & 40 & 14 & 2 & & 150 \\
\hline $01 / 2019$ & & 3 & 22 & 53 & 60 & 28 & 12 & 6 & & 184 \\
\hline $02 / 2019$ & & 5 & 13 & 42 & 40 & 30 & 44 & 9 & & 183 \\
\hline $03 / 2019$ & & 8 & 21 & 52 & 35 & 41 & 31 & 3 & & 191 \\
\hline $04 / 2019$ & & 12 & 23 & 40 & 35 & 38 & 36 & 6 & & 190 \\
\hline $05 / 2019$ & & 1 & 18 & 27 & 45 & 50 & 38 & 8 & 2 & 189 \\
\hline $06 / 2019$ & & 1 & 13 & 23 & 57 & 49 & 39 & 4 & & 186 \\
\hline Total & 6 & 127 & 509 & 795 & 768 & 614 & 505 & 108 & 4 & 3,436 \\
\hline
\end{tabular}

The von Bertalanffy parameters five fish populations were presented in Table 3. Accordingly, the maximum length $\left(L_{\infty}\right)$ of the five fish populations at the five studied sites has the same value of $L_{\infty}=12.6 \mathrm{~cm}$, but the growth coefficient $(K)$ and $t_{0}$ varied with studied site, ranging from $0.49 \mathrm{yr}^{-1}$ to $1.60 \mathrm{yr}^{-1}(K)$ and $-0.12 \mathrm{yr}^{-1}$ to $-0.43 \mathrm{yr}^{-1}\left(t_{0}\right)$.

Table 3. Population parameters of Periophthalmodon septemradiatus and some other gobiid species

\begin{tabular}{|c|c|c|c|c|c|c|c|c|c|c|c|c|}
\hline Species & $\boldsymbol{L}_{\infty}$ & $\boldsymbol{K}$ & $t_{0}$ & $t_{\max }$ & $\boldsymbol{Z}$ & $\boldsymbol{F}$ & $M$ & $\boldsymbol{L}_{c}$ & $\boldsymbol{L}_{c} / \boldsymbol{L}_{\infty}$ & $\boldsymbol{E}$ & $\Phi$, & Source \\
\hline Periophthalmus barbarus & 21.6 & 0.55 & -0.32 & 5.45 & 4.21 & 2.86 & 1.35 & 10.2 & 0.47 & 0.68 & 2.41 & Etim et al. (2002) \\
\hline Pseudapocryptes elongatus & 26.0 & 0.65 & -0.26 & 4.35 & 2.91 & 1.47 & 1.44 & 11.8 & 0.45 & 0.51 & 2.64 & Tran et al. (2007) \\
\hline Periophthalmodon schlosseri & 29.0 & 1.40 & -0.11 & 2.14 & - & - & - & - & - & - & 3.10 & $\begin{array}{l}\text { Mazlan and } \\
\text { Rohaya (2008) }\end{array}$ \\
\hline Parapocryptes serperaster & 25.2 & 0.74 & -0.22 & 4.05 & 3.07 & 1.57 & 1.51 & 14.6 & 0.57 & 0.49 & 2.67 & Dinh et al. (2015b) \\
\hline Trypauchen vagina & 24.2 & 0.56 & -0.03 & 5.56 & 2.73 & 1.29 & 1.44 & 13.8 & 0.57 & 0.53 & 2.50 & Dinh (2018a) \\
\hline Boleophthalmus boddarti & 16.8 & 0.79 & -0.24 & 3.55 & 2.13 & 0.30 & 1.83 & 13.0 & 0.77 & 0.14 & 2.35 & Dinh (2017) \\
\hline Butis butis & 24.0 & 0.61 & -0.04 & 4.92 & 3.40 & 1.98 & 1.42 & 10.5 & 0.44 & 0.58 & 2.55 & Dinh (2018c) \\
\hline Stigmatogobius pleurostigma & 8.6 & 0.83 & -0.07 & 3.61 & 3.48 & 1.17 & 2.31 & 3.8 & 0.44 & 0.34 & 1.79 & $\begin{array}{l}\text { Dinh and Nguyen } \\
\text { (2018) }\end{array}$ \\
\hline \multirow{5}{*}{$\begin{array}{l}\text { Periophthalmodon } \\
\text { septemradiatus }\end{array}$} & 12.6 & 0.68 & -0.30 & 4.41 & 2.21 & 0.39 & 1.82 & 7.0 & 0.55 & 0.18 & 2.03 & \\
\hline & 12.6 & 0.55 & -0.38 & 5.46 & 2.86 & 1.27 & 1.59 & 8.0 & 0.64 & 0.44 & 1.94 & \\
\hline & 12.6 & 0.49 & -0.42 & 6.12 & 1.68 & 0.22 & 1.46 & 7.7 & 0.61 & 0.13 & 1.89 & The present study \\
\hline & 12.6 & 1.10 & -0.18 & 2.73 & 4.05 & 1.58 & 2.47 & 9.5 & 0.76 & 0.39 & 2.24 & \\
\hline & 12.6 & 1.60 & -0.12 & 1.88 & 4.11 & 0.97 & 3.14 & 9.2 & 0.73 & 0.24 & 2.41 & \\
\hline
\end{tabular}



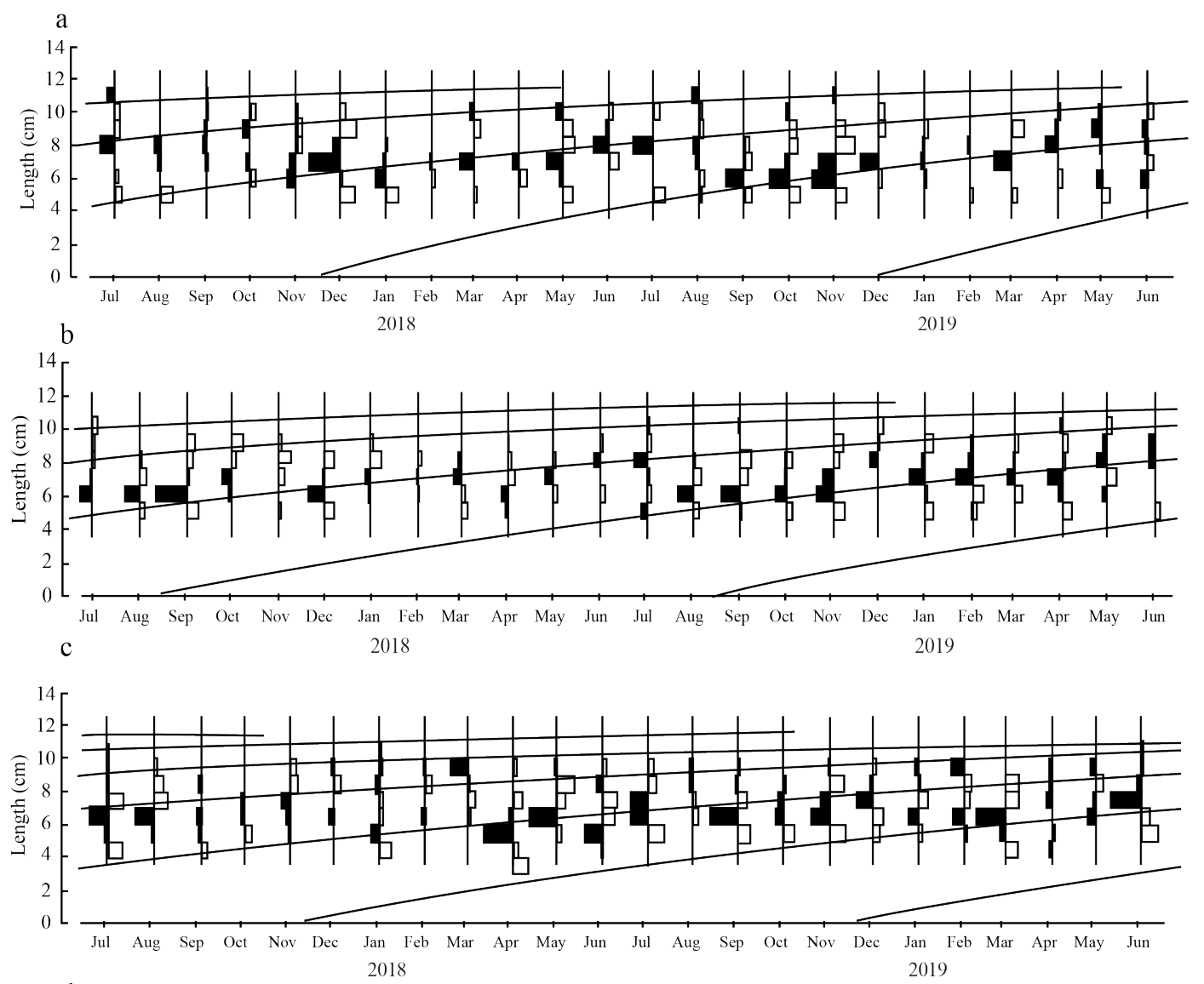

d
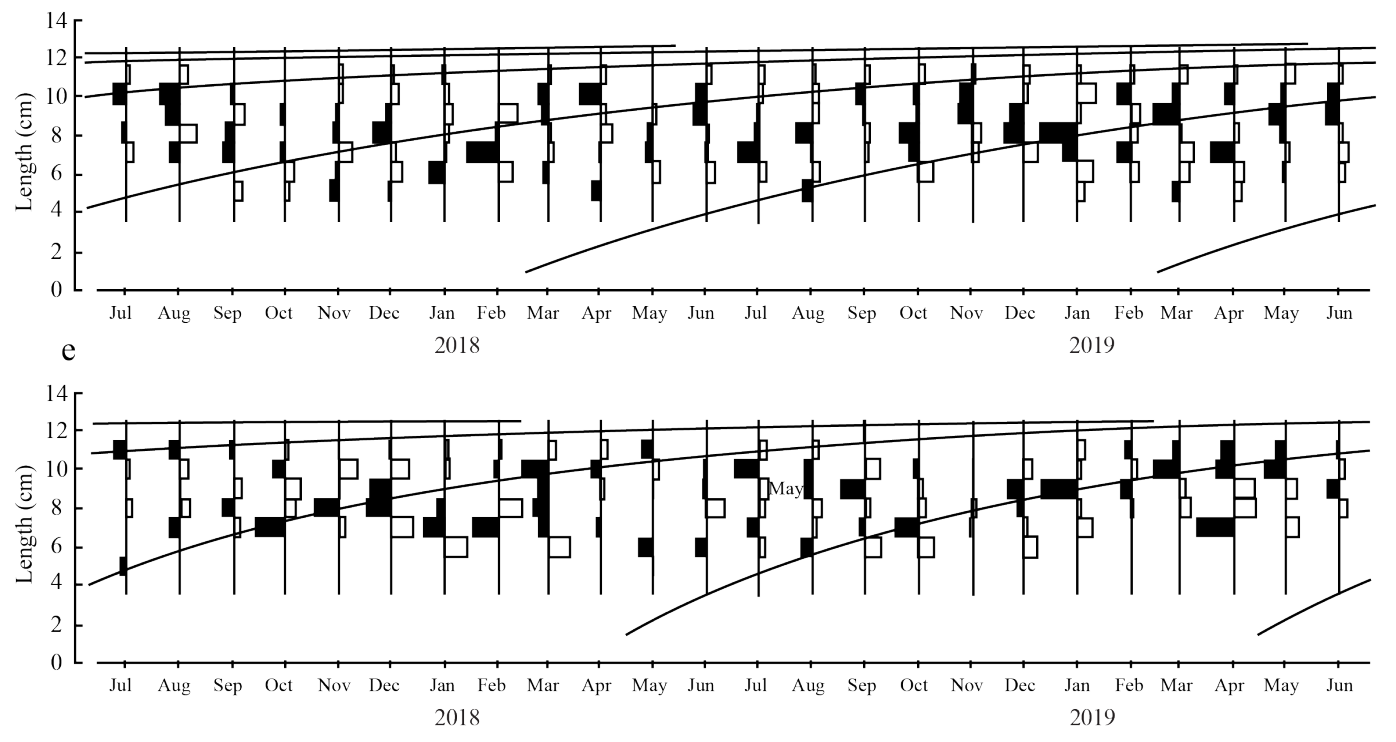

Fig. 2. Length-frequency distribution of Periophthalmodon septemradiatus

(The curves show the increase of fish length over time; a: Long Duc, Long Phu, Soc Trang, $n=709$;

b: An Lac Tay, Ke Sach, Soc Trang, n=730; c: Phu Thu, Cai Rang, Can Tho, n=691; d: Tan Hung, Thot Not,

Can Tho, $\mathrm{n}=649$; and e: Binh Duc, Long Xuyen, An Giang, $\mathrm{n}=657$ )

The total and natural mortalities in $\mathrm{BD}(Z=4.11 \mathrm{yr}, M=3.14 \mathrm{yr})$ reached the highest values among the five populations due to the high erosion of the channel and in the process of concreting (Fig. 3). Fishing mortality $(F=0.22-1.58)$ of all five populations were smaller than natural mortality $(M=1.46-3.14)$ (Fig. 3). 


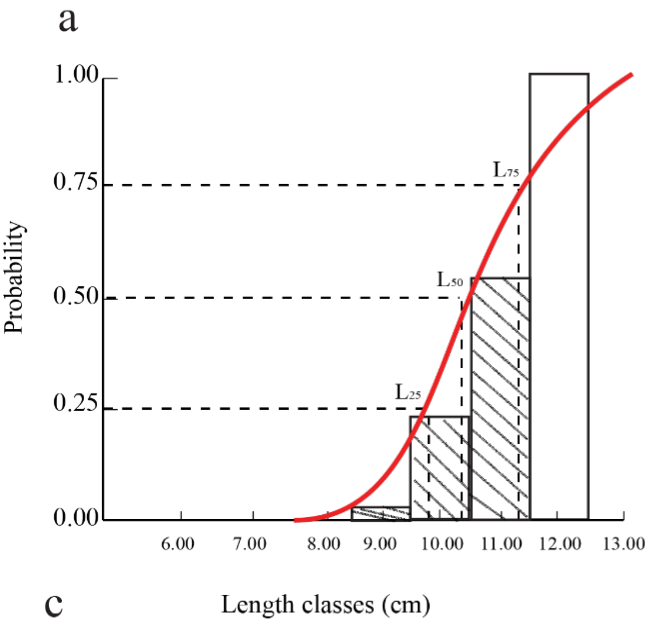

b
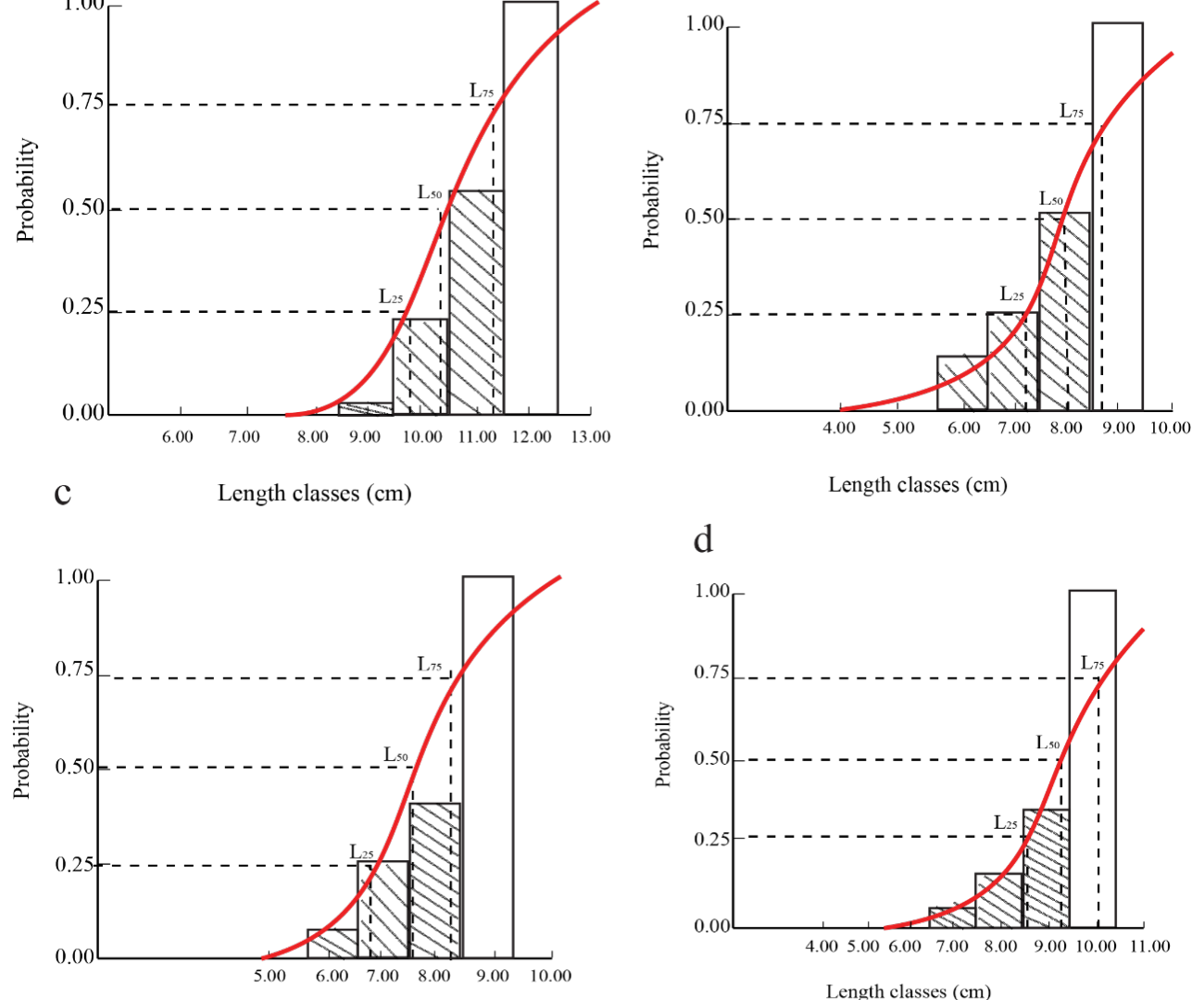

d

Length classes $(\mathrm{cm})$

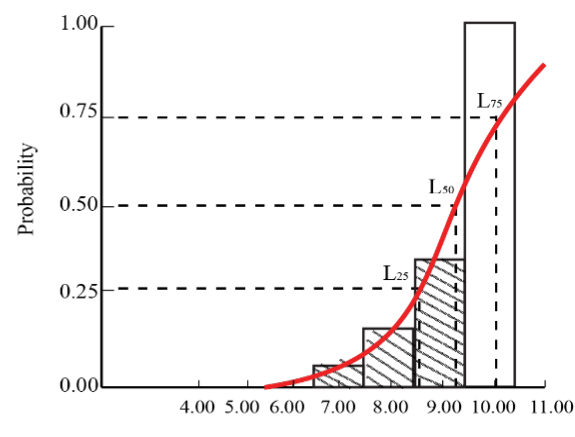

Length classes $(\mathrm{cm})$

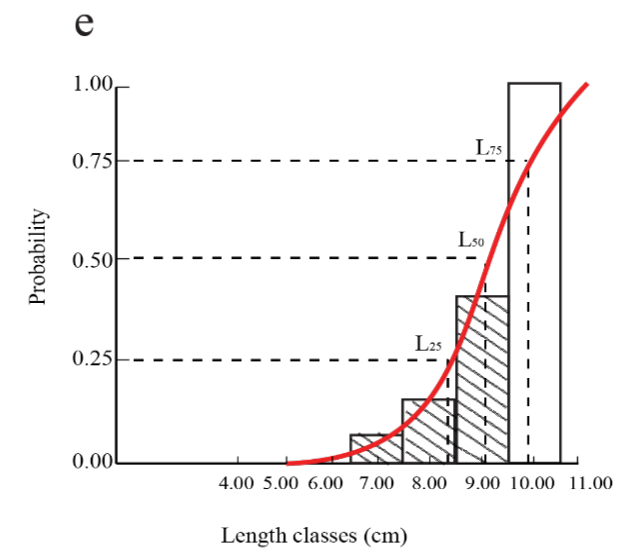

Fig. 3. The length converted catch curve of Periophthalmodon septemradiatus

(a: Long Duc, Long Phu, Soc Trang, $Z=2.21, M=1.82, F=2.39$ and $E=0.18$; b: An Lac Tay, Ke Sach, Soc Trang, $Z=2.86, M=1.59, F=1.27$ and $E=0.44$; c: Phu Thu, Cai Rang, Can Tho, $Z=1.58, M=1.44, F=0.14$ and $E=0.09$; d: Tan Hung, Thot Not, Can Tho, $Z=4.05, M=2.47, F=1.58$ and $E=0.39$; and e: Binh Duc, Long Xuyen, An Giang, $Z=4.11, M=3.14, F=0.97$ and $E=0.24$ )

The first catch length $\left(L_{c}\right.$ or $\left.L_{50}\right)$ of the fish population in LD was the lowest $\left(L_{c}=7.0 \mathrm{~cm}\right.$, Fig. 4$)$ due to the low average length of the fish population $(8.12 \pm 0.05 \mathrm{~cm})$. The $L_{c}$ of $P$. septemradiatus in TH $(9.5 \mathrm{~cm}$, Fig. 4) and in BD (9.2 cm, Fig. 4) were different from those in LD, ALT, and PT since the average total length of this species in $\mathrm{BD}(\mathrm{TL}=9.17 \pm 0.05 \mathrm{~cm})$ and $\mathrm{TH}(\mathrm{TL}=9.03 \pm 0.06 \mathrm{~cm})$ was larger than those in LD, ALT, and PT. The $L_{c} / L_{\infty}$ of $P$. septemradiatus along the Hau River ranged from 0.55 (LD) to $0.76(\mathrm{TH})$. 
a

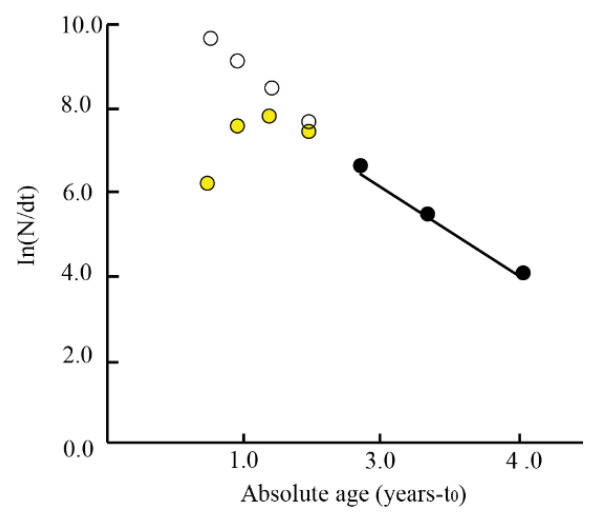

$\mathrm{C}$

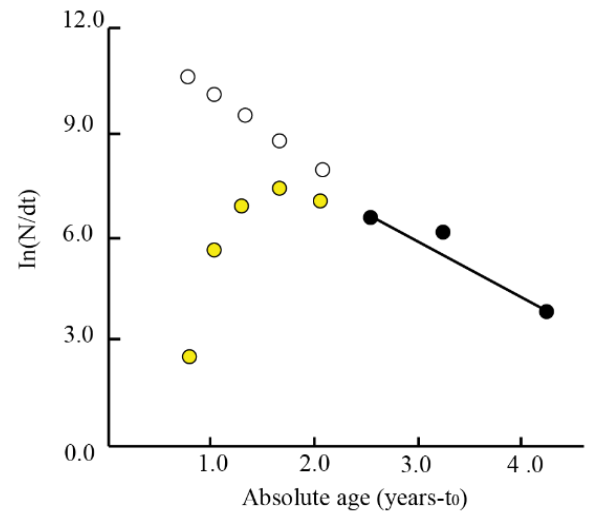

$\mathrm{b}$

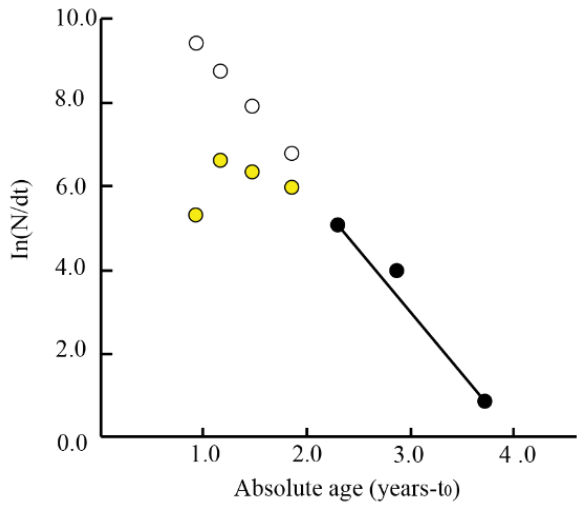

d

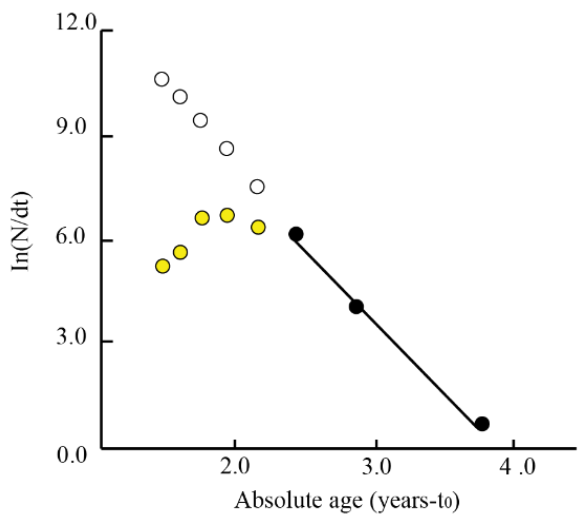

e

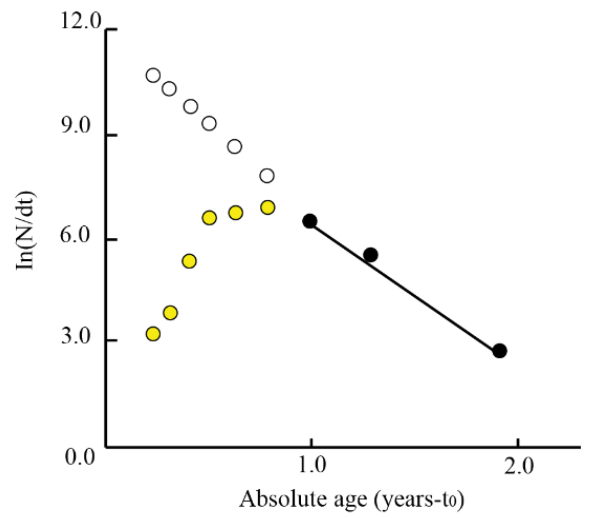

Fig. 4. The probability of capture of Periophthalmodon septemradiatus

(a: Long Duc, Long Phu, Soc Trang, $L_{25}=6.3, L_{50}=7.0$ and $L_{75}=7.7 \mathrm{~cm}$; b: An Lac Tay, Ke Sach, Soc Trang, $L_{25}=7.1, L_{50}=8.0$ and $L_{75}=8.9 \mathrm{~cm}$; c: Phu Thu, Cai Rang, Can Tho, $L_{25}=8.4, L_{50}=9.2$ and $L_{75}=9.9 \mathrm{~cm}$; d: Tan Hung,

Thot Not, Can Tho, $L_{25}=7.1, L_{50}=7.7$ and $L_{75}=8.3 \mathrm{~cm}$; and e: Binh Duc, Long Xuyen, An Giang, $L_{25}=8.6$, $L_{50}=9.5$ and $\left.L_{75}=10.5 \mathrm{~cm}\right)$

The growth performance $\left(\Phi^{\prime}\right)$ of $P$. septemradiatus ranged from 1.89 to 2.41 , reaching the lowest value in PT (1.89) and the highest value in BD (2.41). Conversely, the longevity of this species 
$\left(t_{\max }=1.88-6.12\right)$ reached the highest value in $\mathrm{BD}\left(t_{\max }=6.12 \mathrm{yr}\right)$ and the lowest in $\mathrm{BD}\left(t_{\max }=1.88 \mathrm{yr}\right)$. This suggested that $\Phi^{\prime}$ and $t_{\max }$ had a strong relationship and regulated from the environmental condition among five studied sites. In addition, the landslide in BD could narrow down of riverbanks (e.g., fish habitat), leading to the highest value of $K(1.6)$ and $\mathrm{M}(3.14)$ and the lowest value of $t_{\max }$ (1.88) among five studied regions (Fig. 4).

The exploitation rate $(E)$ of $P$. septemradiatus ranged from 0.14 in PT to 0.44 in ALT. Two populations in ALT and TH were subjected to overexploitation as the $E$ values of these two sites $(0.44$ in ALT and 0.39 in $\mathrm{TH})$ were significantly higher than permission exploitation rates ( $E_{50}$ was 0.402 in ALT and 0.278 in TH, Fig. 5). However, $E$ values of the last three fish populations (0.18 in LD, 0.14 in PT and 0.24 in $\mathrm{BD}$ ) were lower than $E_{50}(0.380$ in $\mathrm{LD}, 0.397$ in PT, and 0.427 in BD, Fig. 5).
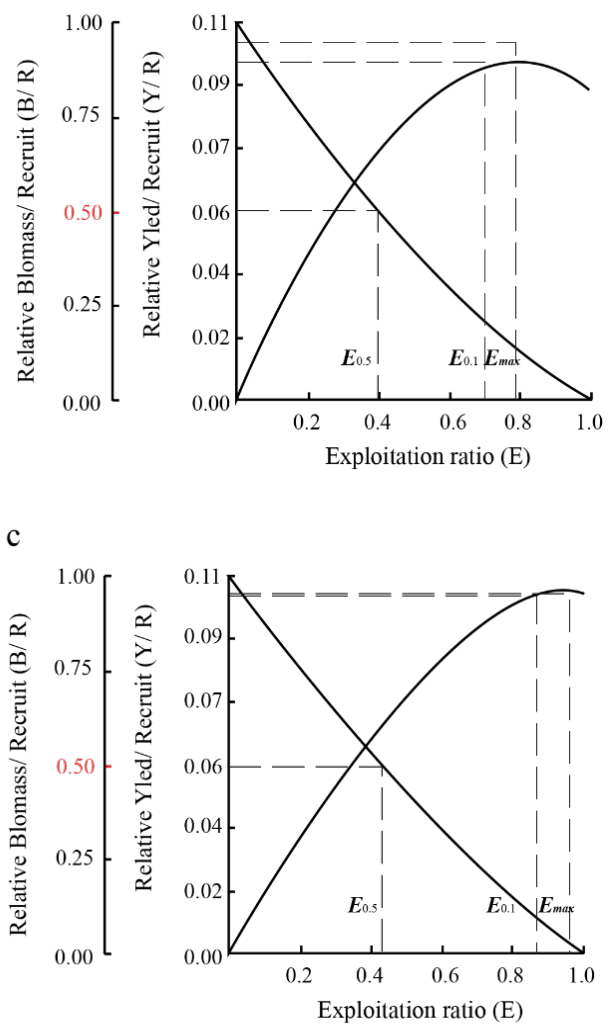

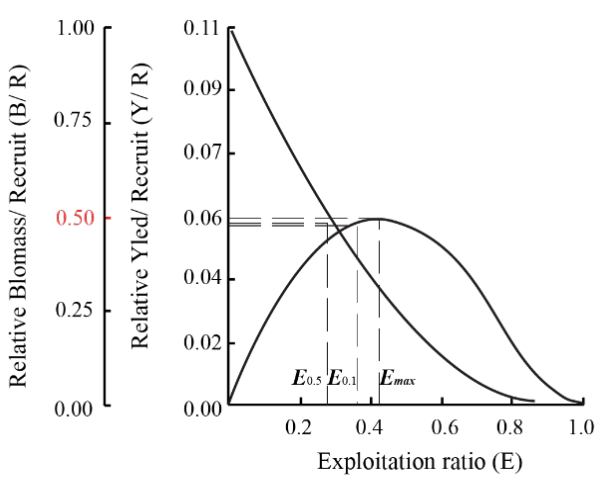

d

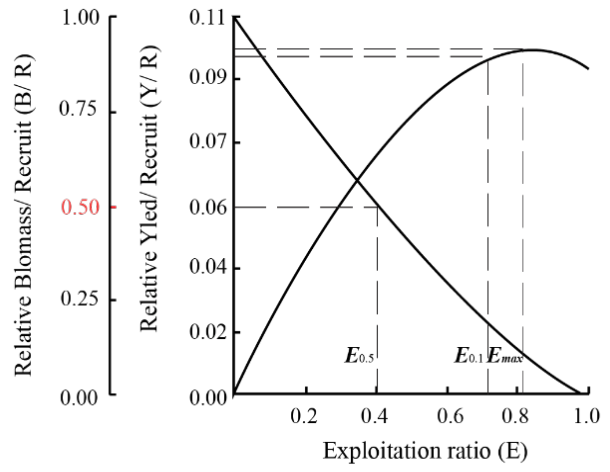

e

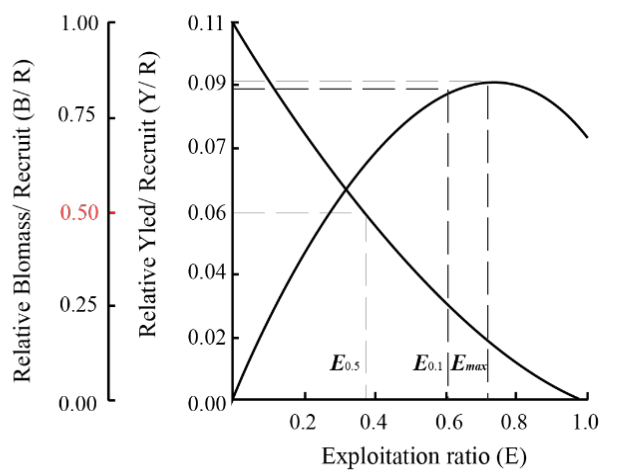

Fig. 5. The relative yield-per-recruit and relative biomass-per-recruit of $\boldsymbol{P}$. septemradiatus (a: Long Duc, Long Phu, Soc Trang, $E_{\max }=0.716, E_{0.1}=0.608$ and $E_{0.5}=0.380$; b: An Lac Tay, Ke Sach, Soc Trang, $E_{\max }=0.815, E_{0.1}=0.713$ and $E_{0.5}=0.402$; c: Phu Thu, Cai Rang, Can Tho, $E_{\max }=0.792, E_{0.1}=0.706$ and $E_{0.5}=0.397$; d: Tan Hung, Thot Not, Can Tho, $E_{\max }=0.421, E_{0.1}=0.355$ and $E_{0.5}=0.278$; and e: Binh Duc, Long Xuyen, An Giang, $E_{\max }=0.956, E_{0.1}=0.868$ and $E_{0.5}=0.427$ ) 


\section{DISCUSSION}

The more active in the male $P$. septemradiatus than females during the period on the muddy flat could lead to the outnumber of males compared to females, which was also found in some other gobiid species living in and out its habitats such as Periophthalmus papilio in Nigeria (Lawson, 2010), Trypauchen vagina (Dinh, 2018b) and Stigmatogobius pleurostigma (Dinh and Tran, 2018) in the Mekong Delta. Conversely, the outnumber of females than males was found in Periophthalmus barbarus in Nigeria (Chukwu et al., 2010) and Butis butis in the Mekong Delta (Dinh and Le, 2017). Likewise, the sex ratio of 1:1 was found in some gobies such as Periophthalmodon schlosseri in Malaysia (Mazlan and Rohaya, 2008), Pseudapocryptes elongatus, Boleophthalmus boddarti and Parapocryptes serpersater in the Mekong Delta (Tran et al., 2007; Dinh et al., 2015a\&b). The difference in sex ratio of these gobies could resulted in the difference in environmental condition of reproductive behavior.

The $K$ of this fish increased from the estuarine sites to riverine sites except for PT which closed some industrial zones, whereas the converse trend was true for $t_{0}$. This suggested the change of these two population parameters was related to the difference of flora among five studied sites. Periophthalmodon septemradiatus tend to be adapted well to the environment than other gobies living in the same its habitats like Parapocryptes serperaster (Dinh et al., 2015b), Boleophthalmus boddarti (Dinh, 2017), Butis butis (Dinh, 2018c), Trypauchen vagina (Dinh, 2018a), Stigmatogobius pleurostigma (Dinh and Nguyen, 2018) and gobies occurring in other places such as Periophthalmus barbarus (Etim et al., 2002) and Periophthalmodon schlosseri (Mazlan and Rohaya, 2008) (Table 3 ). Compared with the $L_{\infty}$ of some goby species, the $L_{\infty}$ of $P$. septemradiatus was shorter than that of Psuedapcryptes elongatus (Tran et al., 2007) and Parapocrytpes serperaster (Dinh et al., 2015b), Trypauchen vagina (Dinh, 2018a), Butis butis (Dinh, 2018c) living in the Mekong Delta, and $P$. schlosseri occurring Malaysia (Mazlan and Rohaya, 2008) (Table 3).

The total and natural mortalities of P. septemradiatus were lower than those in Pseudapocrytpes elongatus (Tran et al., 2007) and Parpacryptes serperaster (Dinh et al., 2015b) in the same habitat (Table 3). This suggested that $P$. septemradiatus may adapt well to the environment than other gobiid species. The $L_{d} / L_{\infty}$ of $P$. septemradiatus was higher than some gobies in the same habitat such as Pseudapocrytpes elongatus (Tran et al., 2007) and Parapocryptes serperaster (Dinh et al., 2015b), Trypauchen vagina (Dinh, 2018a), Butis butis (Dinh, 2018c) and so on (Table 3). It seemed that $P$. septemradiatus was caught sooner than these gobies.

The $\Phi$ ' value of $P$. septemradiatus was smaller than that of P. schlosseri (Mazlan and Rohaya, 2008), but larger than that of Periophthalmus barbarus (Etim et al., 2002), Pseudapocrypes elongatus (Tran et al., 2007) and Parapocryptes serperaster (Dinh et al., 2015b), Trypauchen vagina (Dinh, 2018a), Butis butis (Dinh, 2018c). This could be resulted from the difference in growth coefficients and maximum length between $P$. septemradiatus and other gobies. The $t_{\max }$ of this species is higher than that of Periophthalmodon schlosseri (Mazlan and Rohaya, 2008), but lower than that of some other species such as Pseudapocrytpes elongatus (Tran et al., 2007) and Parapocyteps serperaster (Dinh et al., 2015b), Trypauchen vagina (Dinh, 2018a), Butis butis (Dinh, 2018c) (Table 3).

Two populations in ALT and TH were subjected to overexploitation due to the higher of the $E$ values than the permission exploitation rates. This could result from the exploitation for food and pet demand in these two studied sites. The overexploitation was also found in some other gobies such as Glossogobius giuris (Dinh et al., 2017), Boleophthalmus boddarti (Dinh, 2017), Stigmatogobius pleurostigma (Dinh and Nguyen, 2018) and Trypauchen vagina (Dinh, 2018a) (Table 3). Like the rest three populations in LD, PT and BD, the population of Pseudapocryptes elongatus (Tran et al., 2007), Parapcryptes serperaster (Dinh et al., 2015b) was un-overexploitation (Table 3).

\section{CONCLUSION}

The number of males was higher than that of females. The $L_{\infty}$ was $12.6 \mathrm{~cm}$ in all five populations, but $K$ and $t_{0}$ varied with studied sites. The $K$ value ranged from $0.49 \mathrm{yr}^{-1}$ to $1.6 \mathrm{yr}^{-1}(\mathrm{BD})$, whereas the $t_{0}$ was -0.12 in $\mathrm{BD}$ and -0.43 in PT. The $t_{\max }$ was the lowest value in $\mathrm{BD}$ and the highest one in PT. Its $Z$ and $M$ displayed the highest values in the BD and the lowest one in PT. Conversely, 
the highest and lowest values of $F$ were in $\mathrm{TH}$ and $\mathrm{PT}$, respectively. This goby population was subjected to overfishing in ALT and TH.

\section{ACKNOWLEDGMENTS}

This research is funded by the International Foundation for Science under grant number I-2-A6102-1. We are grateful to staff and students at the Department of Biology, School of Education, Can Tho University for helping us to complete this study.

\section{REFERENCES}

Beverton, R. J. H. and Holt, S. J. (1957). On the dynamics of exploited fish populations. London: Chapman \& Hall, 533pp.

Beverton, R. J. H. and Holt, S. J. (1966). Manual of methods for fish stock assessment. Part II: Tables of yield function. Roma: FAO, 67pp.

Chukwu, K.; Deekae, S. and Gabriel, U. (2010). Reproductive biology of Periopthalmus barbarus (Linneaus 1766) in new Calabar River, Nigeria. Agriculture and Biology Journal of North America, 1(6): 1158-1161.

Diep, A. T.; Dinh, Q. M. and Tran, D. D. (2014). Species composition of gobiidae distributed in the coastal areas, Soc Trang Province. VNU Journal of Sciences: Natural Sciences and Technology, 30(3): 68-76.

Dinh, Q. M.; Nguyen, T. T. G. and Nguyen, T. K. T. (2015a). Reproductive biology of the mudskipper Boleophthalmus boddarti in Soc Trang. Tap chi Sinh hoc, 37(3): 362-369.

Dinh, Q. M.; Qin, J. G. and Tran, D. D. (2015b). Population and age structure of the goby Parapocryptes serperaster (Richardson, 1864; Gobiidae: Oxudercinae) in the Mekong Delta. Turkish Journal of Fisheries and Aquatic Sciences, 15(2): 345-357.

Dinh, Q. M. (2017). Population dynamics of Boleophthalmus boddarti in the Mekong Delta, Vietnam. The Journal of Animal and Plant Sciences, 27(2): 603-610.

Dinh, Q. M. and Le, T. T. M. (2017). Reproductive traits of the duckbill sleeper Butis butis (Hamilton, 1822). Zoological Science, 24(5): 452-458.

Dinh, Q. M.; Phan, Y. N. and Tran, D. D. (2017). Population biology of the goby Glossogobius giuris (Hamilton 1822) caught in the Mekong Delta. Asian Fisheries Sciences, 30(1): 26-37.

Dinh, Q. M. (2018a). Population dynamics of the goby Trypauchen vagina (Gobiidae) at downstream of Hau River, Vietnam. Pakistan Journal of Zoology, 50(1): 105-110.

Dinh, Q. M. (2018b). Aspects of reproductive biology of the red goby Trypauchen vagina (Gobiidae) from the Mekong Delta. Journal of Applied Ichthyology, 34(1): 103-110.

Dinh, Q. M. (2018c). Biological parameters of Butis butis (Hamilton, 1822) population from the Mekong Delta. In: Proceedings scientific research results for training. Kien Giang University, Vietnam, pp. 306-314.

Dinh, Q. M. and Nguyen, N. P. D. (2018). Population and age structure of the goby Stigmatogobius pleurostigma (Perciformes: Gobiidae) from the Mekong Delta. International Journal of Aquatic Science, 9(1): 23-29.

Dinh, Q. M. and Tran, T. T. N. (2018). Reproductive biological traits of the goby Stigmatogobius pleurostigma (Bleeker, 1849) from the Mekong Delta, Vietnam. Indian Journal of Fisheries, 65(1): 20-25.

Dinh, Q. M.; Tran, L. T.; Tran, T. M. T.; To, K. D.; Nguyen, T. T. K. and Tran, D. D. (2019). Variation in diet composition of the mudskipper Periophthalmodon septemradiatus from Hau River, Vietnam. Bulletin of Marine Science, 1-14. https://doi.org/10.5343/bms.2018.0067.

Dinh, Q. M.; Tran, L. T.; Ngo, N. C.; Pham, T. B. and Nguyen, T. T. K. (2020). Reproductive biology of the unique mudskipper Periophthalmodon septemradiatus living from estuary to upstream of the Hau River. Acta Zoologica, 101(2): 206-217.

Etim, L.; King, R. P. and Udo, M. T. (2002). Breeding, growth, mortality and yield of the mudskipper Periophthalmus barbarus (Linneaus 1766) (Teleostei: Gobiidae) in the Imo River estuary, Nigeria. Fisheries Research, 56(3): 227-238. 
Gayanilo, F.; Sparre, P. and Pauly, D. (2005). FAO-ICLARM stock assessment tools II (FiSAT II): User's guide. Roma: FAO, 126pp.

Khaironizam, M. and Norma-Rashid, Y. (2003). First record of the mudskipper, Periophthalmodon septemradiatus (Hamilton) (Teleostei: Gobiidae) from Peninsular Malaysia. Raffles Bulletin of Zoology, 51(1): 97-100.

Lawson, E. O. (2010). Aspects of Reproductive Biology in Mudskipper, Periophthalmus papilio from Mangrove Swamps of Lagos Lagoon, Lagos, Nigeria. Journal of Fisheries International, 5(2): 36-43.

Le, T.; Nguyen, M. T.; Nguyen, V. P.; Nguyen, D. C.; Pham, X. H.; Nguyen, T. S.; Hoang, V. C.; Hoang, P. L.; Le, H. and Dao, N. C. (2006). Provinces and City in the Mekong Delta. Ha Noi: Education Publishing House, 575pp.

Mai, H. V.; Tran, L. X.; Dinh, Q. M.; Tran, D. D.; Murata, M.; Sagara, H.; Yamada, A.; Shirai, K. and Ishimatsu, A. (2019). Land Invasion by the Mudskipper, Periophthalmodon septemradiatus, in fresh and saline waters of the Mekong River. Scientific Reports, 9(1): 14227.

Martin, K. L. M. and Bridges, C. R. (1999). Respiration in Water and Air. In: Horn, M. H., Martin, K. L. M. and Chotkowski, M. A. (Eds.) Intertidal Fishes. San Diego: Academic Press, pp. 5478.

Mazlan, A. G. and Rohaya, M. (2008). Size, growth and reproductive biology of the giant mudskipper, Periophthalmodon schlosseri (Pallas, 1770), in Malaysian waters. Journal of Applied Ichthyology, 24(3): 290-296.

Murdy, E. (2011). Systematics of Oxudercinae. In: Patzner, R. A., Tassell, J. L. V., Kovacic, M.and Kapoor, B. G. (Eds.) The biology of gobies. New Hampshire, United States: Science Publishers, pp. 99-106.

Murdy, E. O. (1989). A taxonomic revision and cladistic analysis of the oxudercine gobies (Gobiidae, Oxudercinae). Australian Museum Journal, 11: 1-93.

Murdy, E. O. and Jaafar, Z. (2017). Taxonomy and systematics review. In: Jaafar, Z. and Murdy, E. O. (Eds.) Fishes out of water: biology and ecology of mudskippers. Boca Raton: CRC Press, pp. 1-36.

Pauly, D. (1979). Theory and management of tropical multispecies stocks: A review with emphasis on Southest Asian dermeral fisheries. ICLARM Studies and Reviews. Philippines ICLARM, 36.

Pauly, D. (1980). On the interrelationships between natural mortality, growth parameters, and mean environmental temperature in 175 fish stocks. Journal du Conseil, 39(2): 175-192.

Pauly, D. and David, N. (1981). ELEFAN I, a BASIC program for the objective extraction of growth parameters from length-frequencies data. Meeresforschung, 28(4): 205-211.

Pauly, D. (1982). Studying single-species dynamics in a tropical multi-species context. In: Pauly, D. and Murphy, G. I., eds. Theory and management of tropical fisheries. Philippines ICLARM, pp. 33-70.

Pauly, D. and Munro, J. L. (1984). Once more on the comparison of growth in fish and invertebrates. Fishbyte, 2(1): 1-21.

Pauly, D. (1987). A review of the ELEFAN system for analysis of length-frequency data in fish and aquatic invertebrates. In: Pauly, D. and Morgan, G., eds. The international conference on the theory and application of length-based methods for stock assessment. Mazzara del Vallo ICLARM, pp. 7-34.

Ricker, W. E. (1975). Computation and interpretation of biological statistics of fish populations. Canada: Department of the Environment, Fisheries and Marine Service, 382pp.

Taylor, C. C. (1958). Cod growth and temperature. Journal du Conseil, 23(3): 366-370.

Tran, D. D.; Ambak, M. A.; Hassan, A. and Nguyen, T. P. (2007). Population biology of the goby Pseudapocryptes elongatus (Cuvier, 1816) in the coastal mud flat areas of the Mekong Delta, Vietnam. Asian Fisheries Sciences, 20(2): 165-179.

Tran, D. D.; Shibukawa, K.; Nguyen, T. P.; Ha, P. H.; Tran, X. L.; Mai, V. H. and Utsugi, K. (2013). Fishes of Mekong Delta, Vietnam. Can Tho: Can Tho University Publisher, 174pp.

Trinh, K. N. and Tran, D. D. (2012). The status of capture fisheries and management of marine fishes in Soc Trang Province. Can Tho University Journal of Science, 24b: 46-55. 